\title{
GMR
}

\section{Clinical significance and expression of PUMA, MCL-1, and p53 in human renal cell carcinoma and para-carcinoma tissues}

\author{
H.B. Xia ${ }^{1 *}$, H.W. Cui ${ }^{2 *}$, L. Su ${ }^{2}$, Z.H. Zhang ${ }^{2}$, X.Y. Yang ${ }^{2}$, S.Q. Ning ${ }^{2}$ and \\ X.L. $\mathrm{Su}^{2}$ \\ ${ }^{1}$ Department of Urology, Affiliated Hospital of Chifeng, \\ Chifeng College, Inner Mongolia, China \\ ${ }^{2}$ Clinical Medical Research Center, \\ Affiliated Hospital of Inner Mongolia Medical University, \\ Hohhot, Inner Mongolia, China \\ *These authors contributed equally to this study. \\ Corresponding author: X.L. Su \\ E-mail: xlsu@hotmail.com
}

Genet. Mol. Res. 16 (3): gmr16039278

Received September 14, 2016

Accepted February 16, 2017

Published July 6, 2017

DOI http://dx.doi.org/10.4238/gmr16039278

Copyright (C) 2017 The Authors. This is an open-access article distributed under the terms of the Creative Commons Attribution ShareAlike (CC BY-SA) 4.0 License.

\begin{abstract}
We investigated the expression level of p53 upregulated modulator of apoptosis (PUMA), myeloid cell leukemia-I (MCL-1), and p53 in renal cell carcinoma (RCC) and para-carcinoma tissues, as well as their clinical significance. The expression levels of PUMA, MCL-1, and p53 in RCC and para-carcinoma tissues were measured using immunohistochemical and quantitative real-time PCR methods. Correlations between protein expression and pathological characteristics were analyzed. Renal clear cell carcinoma showed elevated MCL-1 and $\mathrm{p} 53$ protein expression $(\mathrm{P}>0.05)$ and reduced PUMA expression as compared to that in para-carcinoma tissues. Spearman ranking correlation analysis showed that expression of PUMA, MCL-1, and p53 in was negatively correlated with $\mathrm{RCC}(\mathrm{r}=-0.504, \mathrm{P}=0.001 ; \mathrm{r}=$ $-0.413, \mathrm{P}=0.008)$. We also observed significant correlation between
\end{abstract}

Genetics and Molecular Research 16 (3): gmr16039278 
MCL-1 expression and tumor differentiation $(\mathrm{P}<0.05)$, where MCL-1 expression was significantly higher in well-differentiated adenocarcinoma as compared to that in medium or lowly differentiated adenocarcinoma. In addition, p53 expression was highly correlated with TNM staging $(\mathrm{P}<0.05)$. Single factor analysis on COX's proportional hazard model indicated that postoperative survival rate and prognosis of renal clear cell carcinoma was highly correlated with TNM staging $(\mathrm{P}<$ 0.05). Quantitative real-time PCR analysis indicated higher expression of PUMA, MCL-1, and p53 in cancer tissues as compared to that in para-carcinoma tissues $(\mathrm{P}<0.05)$. The expression of PUMA, MCL-1, and p53 can reflect the biological behavior of renal cell carcinoma, and can be used to indicate tumor invasion, progression, and prognosis.

Key words: Renal cell carcinoma; Para-carcinoma tissue; p53 upregulated modulator of apoptosis; Myeloid cell leukemia-I; p53

\section{INTRODUCTION}

Renal cell carcinoma (RCC), also called renal adenocarcinoma or kidney cancer, is a malignant cancer originating from the renal tubular epithelium. As a commonly seen malignant cancer of the urinary system, RCC accounts for $80-90 \%$ of malignant cancers of the kidney, or $2-3 \%$ of all malignant cancers in adults. The prevalence of RCC is higher in developed countries as compared to developing countries (Penticuff and Kyprianou, 2015; Majer et al., 2015). Most RCC patients are 50-70 years of age, and the proportion of male to female patients is 2:1. In China, the prevalence of RCC is the second highest in all cancers (Guo et al., 2015). The causes of RCC, though not clarified, are possibly smoking, obesity, long-term hemodialysis, or use of anti-inflammatory/analgesic drugs. Some studies have reported high risk of RCC in occupations associated with petroleum, leather, and asbestos. Despite its high prevalence, early diagnosis rate of RCC is low, and early metastasis are common. Typical clinical manifestations of RCC, known as the "classic triad," are hematuria, flank pain, and abdominal mass. In most cases, these symptoms indicate advanced cancer, and metastasis is seen in 30\% of those patients (Maroto and Rini, 2014; Ridge et al., 2014; Zhang et al., 2014). As RCC cells are not sensitive to chemotherapy, radical nephrectomy is currently the most widely adopted form of treatment for RCC. According to previous reports, $50 \%$ patients experience recurrence following surgery. It is therefore essential to determine the biological behavior of RCC at an earlier stage in order to block it and prohibit further metastasis (Das et al., 2015).

Genesis, progression, and metastasis of RCC are complex processes regulated by many cancer-related factors. In recent years, the prevalence of RCC is increasing, particularly in the younger population. This fact is extremely important for identification of the causes and prevention of this disease. Recent development of various molecular biology techniques has brought forth significant progress in cancer research.

p53 upregulated modulator of apoptosis (PUMA) is a pro-apoptotic gene discovered in 2001. PUMA is a member of BH3-only subfamily of the Bcl-2 proteins, and can promote p53-dependent or p53-independent apoptosis (Vávrová and Rezáčová, 2014). PUMA is less expressed in multiple cancer tissues. In addition, exogenous import of PUMA or increasing PUMA expression by removing the inhibitor gene can induce cancer cell apoptosis. (Dey et al.,

Genetics and Molecular Research 16 (3): gmr16039278 
2014) Clinical studies indicated that PUMA expression is absent in many malignant cancers, and that level of PUMA expression is highly correlated to speed of cell apoptosis (Jansson et al., 2004; Karst et al., 2005). As the cancer suppressor gene with the highest correlation with onset of human cancer, p53 is considered to be able to suppress cancer growth via regulation of DNA repair, cell cycle arrest, and induction of apoptosis. However, p53 mutation is the most commonly seen mutation in human cancer. Mutated p53 not only loses its cancer suppression functions, but also acquires oncogenic functions. Lack or inactivation of p53 is associated with onset and progression of more than 50\% of human cancers (Kim et al., 2015; Zaika et al., 2015; Mughal et al., 2016). The myeloid cell leukemia-I (MCL-1) gene also plays an important role in early stages of cancer. As an anti-apoptotic member of the Bcl-2 family, MCL-1 gene was found to be an early induced gene in mononuclear phagocyte differentiation of phorbol esterinduced ML-1, a human myeloid leukemia cell line. MCL-I is located on lq21 of the human chromosome, a variable region in tumorous diseases and precancerous lesions. MCL-1, which is $6502 \mathrm{bp}$ in length, contains three exons and two introns. During transcription, MCL-1 is translated into two proteins due to alternative splicing. The proteins contain $\mathrm{Bcl}-2$ homology (BH) domain, which is a short motif that mediates interaction between proteins of the Bcl2 family, and plays an important role in apoptosis regulation (Perciavalle and Opferman, 2013; Williams and Cook, 2015). MCL-1 contains a BHl-3 domain, but not the BH4 domain. Similar to other proteins of the Bcl-2 family, MCL-1 has a transmembrane domain at the C-terminus, which allows it to be localized on intracellular membranes, particularly on the outer mitochondrial membrane. This allows MCL-1 to regulate important events that occurs in the mitochondrion during apoptosis. MCL-1 is widely distributed in normal tissues of the human body, such as in germinal center cells in the epithelium, the lymphoid tissues, and the neuroendocrine cells. Increased expression of MCL-1 in multiple cancers such as lymphoma, leukemia, multiple myeloma, liver cancer, and lung cancer has been reported (Thomas et al., 2010; Quinn et al., 2011; Belmar and Fesik, 2015). However, few studies have investigated the roles of PUMA, MCL-1, and p53 in RCC. In this study, immunohistochemical and quantitative real-time PCR methods were employed to measure expression levels of PUMA, MCL-1, and p53 in RCC and para-carcinoma tissues. The purpose of this study is to discuss the roles and significance of PUMA, MCL-1, and p53 in the development and metastasis of RCC, and to establish a theoretical basis for diagnosis and prognosis of RCC.

\section{MATERIAL AND METHODS}

\section{Tissue specimens}

Samples were obtained from 47 RCC patients ( 26 men and 21 women) between August 2010 and August 2014 in the First Hospital of Chifeng, Inner Mongolia. The study protocol was approved by the affiliated hospital ethics committee. All patients were fully informed about the study, and they provided written informed consents prior to study enrollment. Patients were between 21 and 78 years of age, with an average age of $56.74 \pm 11.43$ years. Disease severity was graded in accordance with the WHO tumor grading standard 2002: 25 poorly differentiated cases, 19 moderately differentiated cases, and 25 well differentiated cases. Clinical staging of RCC cases was defined according to the TNM standard (UICC, 1997) (Moch et al., 2009): 8 T1 cases, 15 T2 cases, 16 T3 cases, and 8 T4 cases. Up to 41 patients have complete follow-up data. The follow-up period is from 12 to 28 months. All

Genetics and Molecular Research 16 (3): gmr16039278 
tissue samples were soaked in $15 \%$ formalin buffer, fixed, draw materials conventioanlly, dehydrated, embedded in paraffin, and sectioned into 4- $\mu \mathrm{m}$ sections prior to staining. Routine $\mathrm{HE}$ and immunohistochemical staining of PUMA, MCL-1, and p53 were performed.

\section{Immunohistochemistry}

The StrepAvidin-Biotin complex method was employed for immunohistochemical analysis, and staining was performed according to manufacturer's instructions. The general flow of the assay was as follows: 1) routine deparaffinization and hydration of paraffin sections; 2) antigen retrieval at high temperature and pressure for $3 \mathrm{~min} ; 3$ ) serum blocking; 4) addition of 1:100 anti-MCL-1 (rabbit anti-human Mcl-1, bs1352R, Beijing BIOSS), anti-PUMA (rabbit anti-human PUMA, bs1573R, Beijing BIOSS), or ready-to-use anti-P53 (rabbit anti-human p53, MAB-0142, Fuzhou MXB), and leave incubate overnight at $4^{\circ} \mathrm{C} ; 5$ ) addition of readyto-use secondary antibody (KIT5010, Fuzhou MXB), DAB (806180031, Fuzhou MXB); 6) hematoxylin staining; 7) rinsing tissues with tap water; 8) differentiation with hydrochloric acid and alcohol; 9) rinsing; 10) dehydration with alcohol; 11) clarification using xylol; 12) mounting. PBS was used as negative control.

\section{Interpretation of results}

Double-blinded analysis was conducted by experienced pathologists in accordance with the semi-quantitative integration. For immunohistochemical staining of p53, MCL-1, and PUMA, positive result was defined as the presence of yellow particles in the cytoplasm or nucleus. For each case, five random images at high power fields (400X magnification) was observed, and the result was determined using the semi-quantitative integration method: $5 \%$ positivity $=0$ point, $6-25 \%=1$ point, $26-50 \%=2$ points, $51-75 \%=3$ points, and $>75 \%=4$ points. Degree of positivity was defined as follows: yellow $=1$ point, yellowish brown $=2$ points, and brown $=3$ points. Positive rate and staining intensity was categorized as follows: 0 : negative $(-), 1-4$ : weakly positive $(+), 5-8$ : moderately positive $(++), 9-12$ : strongly positive $(+++)$. Total: $\leq 4$ : negative, $>4$ : positive. Positive rate was calculated.

\section{Quantitative real-time PCR}

Total RNA was isolated using the Trizol method (Trizol agent, TaKaRa) according to manufacturer's instructions. The general flow of the assay was as follows: frozen tissue was removed from $-80^{\circ} \mathrm{C}$ refrigerator and cut into the size of mung beans. Approximately $1 \mathrm{~mL}$ Trizol was added for homogenization. Up to $200 \mu \mathrm{L}$ chloroform was added to the solution, and was thoroughly mixed. Sample was cooled at room temperature for 5 min prior to centrifugation at $12,000 \mathrm{rpm}$ and $4^{\circ} \mathrm{C}$ for $15 \mathrm{~min}$. The aqueous phase (approximately 400 $\mu \mathrm{L}$ ) was transferred to a $1.5-\mathrm{mL}$ Eppendorf tube, and $400 \mu \mathrm{L}$ isopropanol was added. The solution was cooled at room temperature for $10 \mathrm{~min}$ prior to being centrifuged at 12,000 rpm and $4^{\circ} \mathrm{C}$ for $10 \mathrm{~min}$. The supernatant was discarded. The deposit was cooled down and washed using 70\% anhydrous ethanol. The deposit was then air dried for 5-10 min and dissolved in $20 \mu \mathrm{L}$ DEPC solution. An ultraviolet spectrophotometer was used to measure $\mathrm{OD}_{260}, \mathrm{OD}_{280}$, and $\mathrm{OD}_{260 / 280}$, and then the purity and concentration of RNA was calculated. RNA mass was estimated using $\mathrm{OD}_{260 / 280}$, which should be 1.8-2.0. RNA concentration was calculated using

Genetics and Molecular Research 16 (3): gmr16039278 
the absorbance value with the following formula: Total RNA concentration $(\mu \mathrm{g} / \mu \mathrm{L})=\mathrm{OD}_{260}$ $\mathrm{x} 40 \times 200 \times 10^{-3}$.

RNA samples were stored in $-80^{\circ} \mathrm{C}$ in accordance with the grouping requirements prior to reverse transcription. Up to $5 \mu \mathrm{g}$ total RNA, $2 \mu \mathrm{L}$ primer Oligo (dT) $15,2 \mu \mathrm{L}$ dNTP mixture, and RNase-free $\mathrm{ddH}_{2} \mathrm{O}$ were added in a sterile, RNase free PCR tube $(14.5 \mu \mathrm{L}$ in total). The mixture was incubated for $5 \mathrm{~min}$ at $65^{\circ} \mathrm{C}$, centrifuged shortly, and then placed on ice. This was followed by the addition of $4 \mu \mathrm{L} 5 \mathrm{X}$ reaction buffer, $0.5 \mu \mathrm{L}$ RNase inhibitor, $1 \mu \mathrm{L}$ revertase, and $1 \mu \mathrm{L} \mathrm{dNTP} \mathrm{mixture} \mathrm{to} \mathrm{make} \mathrm{a} \mathrm{total} \mathrm{volume} \mathrm{of} 20 \mu \mathrm{L}$. The mixture was incubated for $60 \mathrm{~min}\left(42^{\circ} \mathrm{C}\right)$, and heated at $95^{\circ} \mathrm{C}$ for $5 \mathrm{~min}$. The products were grouped and stored at $-20^{\circ} \mathrm{C}$. The cDNA samples were amplified. Reference sequence data of PUMA, MCL-1, and p53 were obtained from GenBank. Primers were designed using the Primer premier 5.0 software, and were synthesized by Sangon Biotech (Shanghai) using human GAPDH as the internal reference. The ABI Prism 7300 fluorogenic quantitative PCR system was used for PCR analysis. The $2^{-\Delta \Delta C t}$ method was used to express relative expressions of genes of interest. Repeated measurements were conducted for genes with upregulated expression. The primer sequences used are shown in Table 1.

Table 1. Primer sequences of PUMA, MCL-1, p53, and human GAPDH.

\begin{tabular}{|c|c|c|}
\hline Target gene & & Primer sequence \\
\hline \multirow[t]{2}{*}{ PUMA } & Upstream & 5'-GAAGAGCAAATGAGCCAAAC-3' \\
\hline & Downstream & 5'-AACCTATGCAATGGGATTGA-3' \\
\hline \multirow[t]{2}{*}{ MCL-1 } & Upstream & 5'-GGACATCAAAAACGAAGACG-3' \\
\hline & Downstream & 5'-GCAGCTTTCTTGGTTTATGG-3' \\
\hline \multirow[t]{2}{*}{$\mathrm{p} 53$} & Upstream & 5'-TTGCAATAGGTGTGCGTCAGA-3' \\
\hline & Downstream & 5'-AGTGCAGGCCAACTTGTTCAG-3' \\
\hline \multirow[t]{2}{*}{ GAPDH } & Upstream & 5'-CGGAGTCAACGGATTTGGTCGTAT-3' \\
\hline & Downstream & 5'-AGCCTTCTCCATGGTGGTGAAGAC-3' \\
\hline
\end{tabular}

The PCR set-up is presented in Table 2.

Table 2. PCR set-up.
\begin{tabular}{l|c}
\hline Reagent & Volume $(\mu \mathrm{L})$ \\
\hline Upstream primer $(10 \mu \mathrm{M})$ & 0.5 \\
\hline Downstream primer $(10 \mu \mathrm{M})$ & 0.5 \\
\hline SYBR Green & 10 \\
\hline cDNA & 4 \\
\hline ddH $_{2} 0$ & 5 \\
\hline Total Volume & 20 \\
\hline
\end{tabular}

Reaction conditions: $50^{\circ} \mathrm{C}$ for $2 \mathrm{~min}, 95^{\circ} \mathrm{C}$ for $10 \mathrm{~min}$, followed by 40 cycles of $95^{\circ} \mathrm{C}$ for $30 \mathrm{~s}$ and $60^{\circ} \mathrm{C}$ for $30 \mathrm{~s}$.

\section{Statistical analysis}

Statistical analysis was conducted using the SPSS13.0 software. Values are expressed as mean $\pm \mathrm{SD}$. The chi-square test was used to compare the expression levels of PUMA, MCL-1, and p53 in different groups. The Pearson product moment correlation coefficient method was used for correlation analysis. Single factor analysis on COX's proportional hazard model was used for postoperative prognosis analysis. Student's $t$-tests were conducted to

Genetics and Molecular Research 16 (3): gmr16039278 
examine expression levels of PUMA, MCL-1, and p53 genes in different groups. The multiple comparison level of multiple sample rates was adjusted using the Bonferroni method, and the coefficient of association (r) is calculated. Statistical difference was defined as $\mathrm{P}<0.05$.

\section{RESULTS}

\section{Expression of PUMA, MCL-1, and p53 in renal clear cell carcinoma and para-carcinoma tissue}

As shown in Table 3 and Figure 1, MCL-1 and 533 have significantly higher expression, whereas PUMA protein has significantly lower expression, in renal clear cell carcinoma as compared to that in para-carcinoma tissue $(\mathrm{P}<0.05)$.

Table 3. Expression of PUMA, MCL-1, and p53 in renal clear cell carcinoma and para-carcinoma tissue.

\begin{tabular}{l|c|c|c|c|c|c}
\hline \multirow{2}{*}{ Group } & \multicolumn{2}{|c|}{ PUMA } & \multicolumn{2}{c|}{ MCL-1 } & \multicolumn{2}{c}{ p53 } \\
\cline { 2 - 7 } & Positive (\%) & Negative (\%) & Positive (\%) & Negative (\%) & Positive (\%) & Negative (\%) \\
\hline RCC group $(\mathrm{N}=47)$ & $17(36.17)$ & $30(63.83)$ & $27(57.45)$ & $20(42.55)$ & $29(61.70)$ & $18(38.30)$ \\
\hline Para-carcinoma tissue $(\mathrm{N}=47)$ & $32(68.09)$ & $15(31.91)$ & $8(17.02)$ & $39(82.98)$ & $9(19.15)$ & $38(80.85)$ \\
\hline$\chi^{2}$ & \multicolumn{2}{|c|}{5.23} & \multicolumn{2}{|c|}{9.43} & \multicolumn{2}{c}{15.31} \\
\hline P value & \multicolumn{2}{|c|}{$<0.05$} & \multicolumn{2}{c|}{$<05$} & \multicolumn{2}{c}{$<0.05$} \\
\hline
\end{tabular}
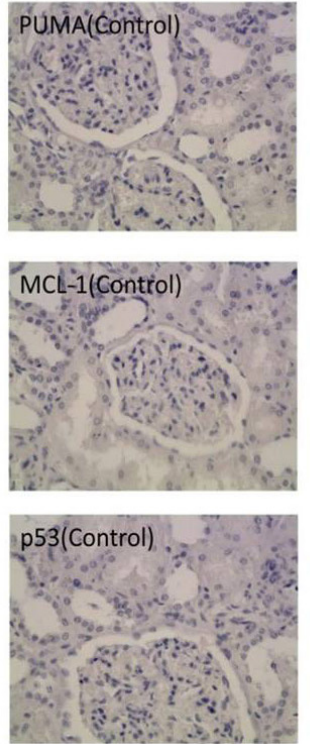
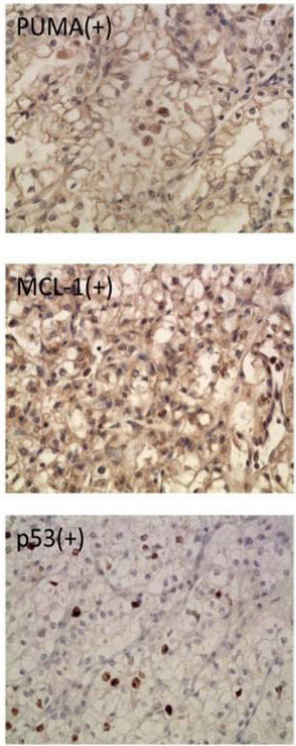
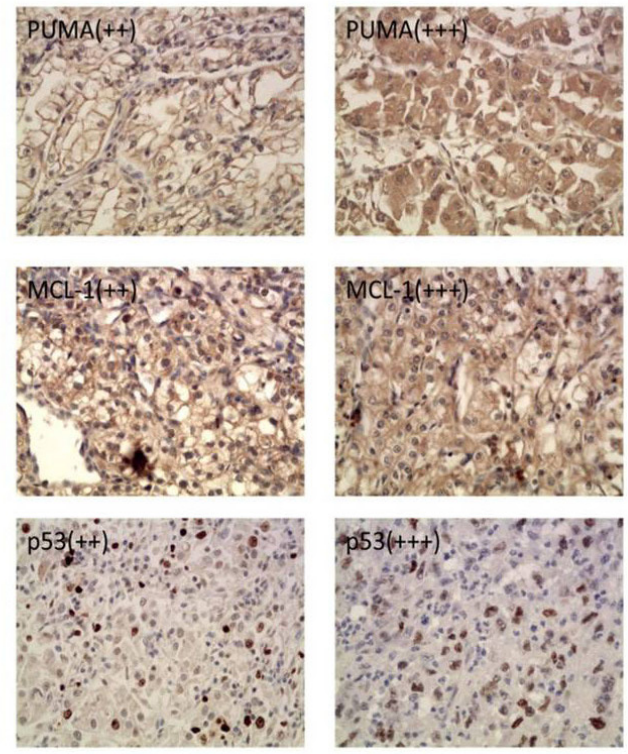

Figure 1. Expression of PUMA, MCL-1, and p53 in renal clear cell carcinoma and para-carcinoma tissue Images are at 400X magnification; $(+)$ : weakly positive. $(++)$ : moderately positive. $(+++)$ : strongly positive.

\section{Correlation between RCC and expression of PUMA, MCL-1, and P53}

According to results from Pearson product moment correlation coefficient methods, expression levels of PUMA, MCL-1, and p53 are negatively correlated with RCC (Table 4).

Genetics and Molecular Research 16 (3): gmr16039278 
Table 4. Correlation between RCC and expression of PUMA, MCL-1, and p53.

\begin{tabular}{|c|c|c|c|c|c|c|}
\hline \multirow[t]{2}{*}{ Factors } & \multicolumn{2}{|c|}{ PUMA } & \multicolumn{2}{|c|}{ Mcl-1 } & \multicolumn{2}{|c|}{$\mathrm{p} 53$} \\
\hline & $\mathrm{r}$ & $\mathrm{P}$ value & $\mathrm{r}$ & $\mathrm{P}$ value & $\mathrm{r}$ & $\mathrm{P}$ value \\
\hline PUMA & - & - & -0.504 & 0.001 & -0.413 & 0.008 \\
\hline Mcl-1 & -0.504 & 0.001 & - & - & 0.517 & 0.006 \\
\hline $\mathrm{p} 53$ & -0.413 & 0.008 & 0.517 & 0.006 & - & - \\
\hline
\end{tabular}

\section{Correlation between expression of PUMA, MCL-1, and p53 and clinical and pathological characteristics}

In RCC tissue of 47 cases, PUMA expression showed no significant correlation with gender, tumor differentiation, or TNM staging $(\mathrm{P}>0.05)$. A significant correlation was observed between MCL-1 expression and tumor differentiation $(\mathrm{P}<0.05)$. MCL-1 expression in well-differentiated adenocarcinoma was significantly higher than that in medium and lowly differentiated adenocarcinoma, but was not significantly correlated with gender or TNM staging $(\mathrm{P}>0.05)$. The expression of $\mathrm{p} 53$ was highly correlated with TNM staging $(\mathrm{P}<0.05)$, but not with gender or tumor differentiation $(\mathrm{P}>0.05)$ (Table 5).

\begin{tabular}{|c|c|c|c|c|c|c|c|c|c|c|c|}
\hline \multirow{2}{*}{\multicolumn{2}{|c|}{ Variable }} & \multirow[t]{2}{*}{$\mathrm{N}$} & \multicolumn{3}{|c|}{ PUMA expression } & \multicolumn{3}{|c|}{ MCL-1 expression } & \multicolumn{3}{|c|}{ p53 expression } \\
\hline & & & Positive rate $(\mathrm{N}, \%)$ & $\chi^{2}$ & P value & Positive rate $(\mathrm{N}, \%)$ & $\chi^{2}$ & $P$ value & Positive rate $(\mathrm{N}, \%)$ & $\chi^{2}$ & $P$ value \\
\hline \multirow[t]{2}{*}{ Gender } & Male & 26 & $9(34.62 \%)$ & \multirow[t]{2}{*}{0.661} & \multirow[t]{2}{*}{0.804} & $15(57.69 \%)$ & \multirow[t]{2}{*}{0.021} & \multirow[t]{2}{*}{0.901} & $14(53.84 \%)$ & \multirow[t]{2}{*}{0.03} & \multirow[t]{2}{*}{0.958} \\
\hline & Female & 21 & $8(38.10 \%)$ & & & $13(61.90 \%)$ & & & $12(57.14 \%)$ & & \\
\hline \multirow{3}{*}{$\begin{array}{l}\text { Tumor } \\
\text { differentiation }\end{array}$} & Well & 3 & $1(33.33 \%)$ & \multirow[t]{3}{*}{1.787} & \multirow[t]{3}{*}{0.451} & $3(100 \%)$ & \multirow[t]{3}{*}{8.816} & \multirow[t]{3}{*}{0.012} & $2(66.67 \%)$ & \multirow[t]{3}{*}{4.616} & \multirow[t]{3}{*}{0.1} \\
\hline & \begin{tabular}{|l} 
Moderately \\
\end{tabular} & 19 & $9(47.37 \%)$ & & & $8(42.11 \%)$ & & & $10(52.63 \%)$ & & \\
\hline & \begin{tabular}{|l|} 
Poorly \\
\end{tabular} & 25 & $6(24.0 \%)$ & & & $13(61.90 \%)$ & & & $13(52.0 \%)$ & & \\
\hline \multirow[t]{4}{*}{ T staging } & \begin{tabular}{|l|l|} 
T1 \\
\end{tabular} & 8 & $4(50.0 \%)$ & \multirow[t]{4}{*}{4.897} & \multirow[t]{4}{*}{0.179} & $4(50.0 \%)$ & \multirow[t]{4}{*}{0.531} & \multirow[t]{4}{*}{0.912} & $2(25.0 \%)$ & \multirow[t]{4}{*}{8.411} & \multirow[t]{4}{*}{0.035} \\
\hline & $\mathrm{T} 2$ & 15 & $8(53.33 \%)$ & & & $10(66.67 \%)$ & & & $5(33.33 \%)$ & & \\
\hline & T3 & 16 & $6(37.5 \%)$ & & & $10(62.5 \%)$ & & & $9(56.25 \%)$ & & \\
\hline & T4 & 4 & $1(25.0 \%)$ & & & $2(25.0 \%)$ & & & $3(75.0 \%)$ & & \\
\hline
\end{tabular}

\section{Single factor analysis on COX's proportional hazard model of postoperative prognosis of renal clear cell carcinoma}

Results from single factor analysis on COX's proportional hazard model of postoperative prognosis of RCC indicated that prognosis of RCC is highly correlated with TNM staging ( $\mathrm{P}<$ $0.05)$, but not with gender, age, and tumor differentiation $(\mathrm{P}>0.05)$ (Table 6).

Table 6. Single factor analysis on COX's proportional hazard model of postoperative prognosis of renal clear cell carcinoma.

\begin{tabular}{l|c|c|c|c|c|c|c}
\hline Variable & Standard error (SE) & Wald & d.f. & P value & Relative risk & \multicolumn{2}{|c}{$95 \%$ CI for OR } \\
\cline { 5 - 8 } & & & & & \multicolumn{2}{|c}{ Lower } & Upper \\
\hline Gender & 0.673 & 0.010 & 1 & 0.921 & 1.017 & 0.278 & 3.948 \\
\hline Age & 0.421 & 0.493 & 1 & 0.580 & 1.331 & 0.568 & 2.914 \\
\hline Tumor differentiation & 0.363 & 1.417 & 1 & 0.252 & 1.532 & 0.787 & 2.952 \\
\hline TNM staging & 0.264 & 5.135 & 1 & 0.023 & 1.784 & 1.097 & 2.831 \\
\hline
\end{tabular}

\section{DISCUSSION}

Renal cancer is a malignant cancer of the urinary system. Its development and metastasis are governed by complex processes with multiple factors. Activation of cancer 
genes, deactivation of cancer suppressor genes, and over-expression of protein, among others, are important factors associated with the onset and progression of cancer (Xu et al., 2015a; Ferraiuolo et al., 2016). The p53 gene, which is located on 17P13.1 of the human chromosome, is $16-20 \mathrm{~kb}$ in length, and its mRNA, which is $2.5 \mathrm{~kb}$, encodes a 393 -amino-acid long protein. The gene is called p53 due to its molecular weight, which is $53 \mathrm{kDa}$. Two types of p53 exist, namely, wild type p53 (wtp53) and mutant type p53 (mtp53). The wtp53 is a cancer suppressor gene, and plays a role of a "molecular policeman" in growth, differentiation, and proliferation of cells. The p53 protein is a nucleic acid protein encoded by the p53 gene, and is associated with cell division cycles. Mutation of p53 is the most commonly seen mutation in human cancer. Lack or inactivation of p53 is associated with the onset and progress of more than $50 \%$ human cancers (Sabapathy, 2015). Under physiological conditions, the mtp53 proteins exhibit stable metabolism and long half-life, and can easily accumulate inside the cells. This is the reason for the p53 detected using general immunohistochemical methods is mostly in the mtp53 form. mtp53 is over-expressed in gastric, pancreatic, and liver cancers, and has been correlated with caner differentiation and disease prognosis (Jansson et al., 2004; de Oliveira et al., 2015; Parrales and Iwakuma, 2015). In the 47 RCC tissue samples obtained in this study, positive expression rate of $\mathrm{mtp} 53$ was $61.70 \%$, and positive expression rate of mtp53 in para-carcinoma tissue was $19.15 \%(\mathrm{P}<0.05)$. In addition, expression of $\mathrm{p} 53$ in RCC tissue was significantly higher than that in the para-carcinoma tissue $(\mathrm{P}<0.05)$. This suggested that mutation of p53 results in loss of the function of wtp53 to suppress cancers. Moreover, the product of p53 mutation, mtp53, promoted cell transformation and over-proliferation, resulting in tumorigenesis. Therefore, lack or mutation of wtp53 plays an important role in the onset and development of RCC. The result of this study also indicated that expression of p53 is highly correlated with TNM staging $(\mathrm{P}<0.05)$, but not with gender or tumor differentiation ( $\mathrm{P}$ $>0.05$ ). The result of single factor analysis on COX's proportional hazard model indicated that post-operative survival rate and prognosis of renal clear cell carcinoma was highly correlated with TNM staging $(\mathrm{P}<0.05)$. However, gender, age, and tumor differentiation showed no significant correlation with prognosis of renal clear cell carcinoma $(\mathrm{P}>0.05)$. Our results suggested that mtp53 is correlated with adverse prognosis of RCC, and can be used as an indicator of adverse prognosis in clinical practice.

PUMA is located in 19q13.3-13.4, and its cDNA is $1.9 \mathrm{~kb}$ in length. PUMA $\alpha$ encodes a protein of 193 amino acids that contains a Bcl-2 homologous domain (BH3), which exists in many apoptosis factors of the Bcl-2 family. According to relevant studies, BH3 domain is the only domain in PUMA that is homologous to other known proteins, and PUMA without BH3 does not have an apoptosis-inducing effect. PUMA is an essential pro-apoptosis gene downstream of wtp53, and loss of PUMA was associated with onset of many cancers (Adams and Cory, 2007; Xu et al., 2015b). We found that expression of PUMA protein in 47 RCC tissue samples was significantly lower as compared to that in para-carcinoma tissue (36.17 vs $68.09 \%, \mathrm{P}<0.05$ ). In addition, expression rate of PUMA gene in cancer tissue was significantly higher as compared to that in para-carcinoma tissue (36.17 vs 68.09\%, $\mathrm{P}<0.05)$, suggesting a correlation between proliferation and canceration of RCC cells and loss/deactivation of PUMA. However, no significant correlation was found between PUMA expression and gender, tumor differentiation, or TNM staging $(\mathrm{P}>0.05)$.

The MCL-1 gene, which is located on 1q21 of the human chromosome, plays an important role in cell differentiation and apoptosis. MCL-1 is an anti-apoptosis factor of the Bcl-2 family, and demonstrates overlapping or rearrangement in cancer and precancerous

Genetics and Molecular Research 16 (3): gmr16039278 
lesions. The main function of MCL-1 is to maintain mitochondrial membrane stability and to inhibit the release of cytochrome $\mathrm{C}$, thereby promoting cell survival and inhibiting cell apoptosis. MCL-1 is highly expressed in multiple cancer tissues, and over-expression of MCL-1 may result in tumors of the human hematopoietic system and solid tumors (Kitada and Reed, 2004; Inuzuka et al., 2011). Another study revealed that expression of MCL-1 increases gradually during evolution of normal cervical tissue into cervical cancer, and negative correlation was observed between MCL-1 expression and differentiation of cervical cancer, suggesting that MCL-1 exhibits anti-apoptosis and growth-promoting effects. Therefore, measurement of MCL-1 expression can be used in prognosis prediction of cervical cancer (Wei et al., 2001). Our study indicated that both the MCL-1 gene and protein have higher expression in RCC as compared to that in para-carcinoma tissue, and that MCL-1 protein expression was significantly correlated with tumor differentiation $(\mathrm{P}<0.05)$. The expression rate of MCL-1 in well-differentiated adenocarcinoma was significantly higher than that in poorly or moderately differentiated adenocarcinoma. However, MCL-1 expression showed no correlation with gender or TNM staging $(\mathrm{P}>0.05)$. These results suggested that MCL1 protein inhibits the timely removal of damaged or mutated cells, which can develop into cancer. It therefore plays a role in the onset and development of RCC.

We also examined correlation between PUMA, MCL-1, and p53 protein expressions and RCC in this study. Apoptosis is a complex process regulated by many factors, and involves interaction of various positive and negative gene families. Failure in apoptosis regulation results in over-proliferation of cells, increased potential for malignant cells, and development of cancer (Hata et al., 2015). The result of this study indicated a negative correlation between mtp53 and expression of MCL-1 and PUMA, suggesting that PUMA plays a role in RCC through endogenous p53. Following wtp53 mutation, wtp53 loses the function of positive regulation on PUMA, which results in loss of PUMA expression. We also found that PUMA was negatively correlated with MCL-1 expression, suggesting that loss of PUMA expression in RCC results in reduced or loss of MCL-1, neutralizing its effects. The possible pathway by which pro-apoptotic PUMA acts on RCC is via p53-PUMA-MCL-1. During RCC progression, wtp53, PUMA, MCL-1, and other cancer genes and can inhibit tumor suppressor genes through caspase-dependent/independent apoptosis signaling route, and resulting in RCC development.

In conclusion, the onset and development of RCC have complex mechanisms that involve multiple cancer genes and cancer suppressor genes. The prognosis of RCC is poor due to its high degree of malignancy and difficulties in early detection. This study explored the expression of PUMA, mtP53, and MCL-1 genes and proteins in RCC using limited samples and relatively simple methods. We believe that future studies on biological characteristics of RCC and cancer-related genes will be more in-depth and detailed. The mechanism of onset, development, invasion, and metastasis, and therapies for RCC can be achieved through studies related to apoptosis, cell cycle regulation, and the extracellular microenvironment.

\section{Conflicts of interest}

The authors declare no conflict of interest.

\section{ACKNOWLEDGMENTS}

The research received no specific grants from any founding agency.

Genetics and Molecular Research 16 (3): gmr16039278 


\section{REFERENCES}

Adams JM and Cory S (2007). The Bcl-2 apoptotic switch in cancer development and therapy. Oncogene 26: 1324-1337. http://dx.doi.org/10.1038/sj.onc. 1210220

Belmar J and Fesik SW (2015). Small molecule Mcl-1 inhibitors for the treatment of cancer. Pharmacol. Ther. 145: 76-84. http://dx.doi.org/10.1016/j.pharmthera.2014.08.003

Das CJ, Thingujam U, Panda A, Sharma S, et al. (2015). Perfusion computed tomography in renal cell carcinoma. World J. Radiol. 7: 170-179. http://dx.doi.org/10.4329/wjr.v7.i7.170

de Oliveira GA, Rangel LP, Costa DC and Silva JL (2015). Misfolding, aggregation, and disordered segments in c-Abl and p53 in human cancer. Front. Oncol. 5: 97. http://dx.doi.org/10.3389/fonc.2015.00097

Dey P, Ström A and Gustafsson JÅ (2014). Estrogen receptor b upregulates FOXO3a and causes induction of apoptosis through PUMA in prostate cancer. Oncogene 33: 4213-4225. http://dx.doi.org/10.1038/onc.2013.384

Ferraiuolo M, Di Agostino S, Blandino G and Strano S (2016). Oncogenic intra-p53 family member interactions in human cancers. Front. Oncol. 6: 77. http://dx.doi.org/10.3389/fonc.2016.00077

Guo J, Ma J, Sun Y, Qin S, et al.; written; CSCO Renal Cell Carcinoma Committee (2015). Chinese guidelines on the management of renal cell carcinoma (2015 edition). Ann. Transl. Med. 3: 279.

Hata AN, Engelman JA and Faber AC (2015). The BCL2 family: key mediators of the apoptotic response to targeted anticancer therapeutics. Cancer Discov. 5: 475-487. http://dx.doi.org/10.1158/2159-8290.CD-15-0011

Inuzuka H, Fukushima H, Shaik S, Liu P, et al. (2011). Mcl-1 ubiquitination and destruction. Oncotarget 2: 239-244. http:// dx.doi.org/10.18632/oncotarget.242

Jansson A, Arbman G and Sun XF (2004). mRNA and protein expression of PUMA in sporadic colorectal cancer. Oncol. Rep. 12: 1245-1249.

Karst AM, Dai DL, Martinka M and Li G (2005). PUMA expression is significantly reduced in human cutaneous melanomas. Oncogene 24: 1111-1116. http://dx.doi.org/10.1038/sj.onc.1208374

Kim MP, Zhang Y and Lozano G (2015). Mutant p53: multiple mechanisms define biologic activity in cancer. Front. Oncol. 5: 249. http://dx.doi.org/10.3389/fonc.2015.00249

Kitada S and Reed JC (2004). MCL-1 promoter insertions dial-up aggressiveness of chronic leukemia. J. Natl. Cancer Inst. 96: 642-643. http://dx.doi.org/10.1093/jnci/djh153

Majer W, Kluzek K, Bluyssen H and Wesoły J (2015). Potential approaches and recent advances in biomarker discovery in clear-cell renal cell carcinoma. J. Cancer 6: 1105-1113. http://dx.doi.org/10.7150/jca.12145

Maroto P and Rini B (2014). Molecular biomarkers in advanced renal cell carcinoma. Clin. Cancer Res. 20: 2060-2071. http://dx.doi.org/10.1158/1078-0432.CCR-13-1351

Moch H, Artibani W, Delahunt B, Ficarra V, et al. (2009). Reassessing the current UICC/AJCC TNM staging for renal cell carcinoma. Eur. Urol. 56: 636-643. http://dx.doi.org/10.1016/j.eururo.2009.06.036

Mughal TI, Radich JP, Deininger MW, Apperley JF, et al. (2016). Chronic myeloid leukemia: reminiscences and dreams. Haematologica 101: 541-558. http://dx.doi.org/10.3324/haematol.2015.139337

Parrales A and Iwakuma T (2015). Targeting oncogenic mutant p53 for cancer therapy. Front. Oncol. 5: 288. http://dx.doi. org/10.3389/fonc. 2015.00288

Penticuff JC and Kyprianou N (2015). Therapeutic challenges in renal cell carcinoma. Am. J. Clin. Exp. Urol. 3: 77-90.

Perciavalle RM and Opferman JT (2013). Delving deeper: MCL-1's contributions to normal and cancer biology. Trends Cell Biol. 23: 22-29. http://dx.doi.org/10.1016/j.tcb.2012.08.011

Quinn BA, Dash R, Azab B, Sarkar S, et al. (2011). Targeting Mcl-1 for the therapy of cancer. Expert Opin. Investig. Drugs 20: 1397-1411. http://dx.doi.org/10.1517/13543784.2011.609167

Ridge CA, Pua BB and Madoff DC (2014). Epidemiology and staging of renal cell carcinoma. Semin. Intervent. Radiol. 31: 3-8. http://dx.doi.org/10.1055/s-0033-1363837

Sabapathy K (2015). The contrived mutant p53 oncogene - beyond loss of functions. Front. Oncol. 5: 276. http://dx.doi. org $/ 10.3389 /$ fonc. 2015.00276

Thomas LW, Lam C and Edwards SW (2010). Mcl-1; the molecular regulation of protein function. FEBS Lett. 584: 29812989. http://dx.doi.org/10.1016/j.febslet.2010.05.061

Vávrová J and Rezáčová M (2014). Importance of proapoptotic protein PUMA in cell radioresistance. Folia Biol. (Praha) 60: 53-56.

Wei LH, Kuo ML, Chen CA, Chou CH, et al. (2001). The anti-apoptotic role of interleukin-6 in human cervical cancer is mediated by up-regulation of Mcl-1 through a PI 3-K/Akt pathway. Oncogene 20: 5799-5809. http://dx.doi. org/10.1038/sj.onc. 1204733

Williams MM and Cook RS (2015). Bcl-2 family proteins in breast development and cancer: could Mcl-1 targeting

Genetics and Molecular Research 16 (3): gmr16039278 
PUMA, MCL-1, and p53 and human renal cell carcinoma

overcome therapeutic resistance? Oncotarget 6: 3519-3530. http://dx.doi.org/10.18632/oncotarget.2792

Xu G, Yang M, Huang J and Jin J (2015a). Coexistence of multiple myeloma and clear cell renal cell carcinoma: a case report and review of literature. Int. J. Clin. Exp. Pathol. 8: 7627-7630.

Xu T, Fan B, Lv C and Xiao D (2015b). Slug mediates nasopharyngeal carcinoma radioresistance via downregulation of PUMA in a p53-dependent and -independent manner. Oncol. Rep. 33: 2631-2638.

Zaika AI, Wei J, Noto JM and Peek RM (2015). Microbial regulation of p53 tumor suppressor. PLoS Pathog. 11: e1005099. http://dx.doi.org/10.1371/journal.ppat.1005099

Zhang GM, Zhu Y and Ye DW (2014). Metabolic syndrome and renal cell carcinoma. World J. Surg. Oncol. 12: 236. http:// dx.doi.org/10.1186/1477-7819-12-236

Genetics and Molecular Research 16 (3): gmr16039278 